\title{
The Occurrence of Major Viruses Infecting Zucchini Squash (Cucurbita pepo L.) in Morocco
}

\author{
Mohamed Afechtal, \\ National Institute for Agricultural Research (INRA), \\ Regional Center of Kénitra, Laboratory of Virology, Kénitra, Morocco \\ Ahmed Aarabe, \\ Bouchra Chebli, \\ School of Applied Sciences, University Ibn Zohr, Agadir, Morocco \\ Majid Mounir, \\ Department of Food Science and Nutrition, \\ Hassan II Institute of Agronomy and Veterinary Medicine, Rabat, Morocco
}

Doi: 10.19044/esj.2019.v15n12p188 URL:http://dx.doi.org/10.19044/esj.2019.v15n12p188

\begin{abstract}
Zucchini squash, Cucurbita pepo L., is one of the most economically important vegetable crops in Morocco. Virus diseases are a major factor in limiting production of zucchini squash in the country. During the growing seasons 2015, 2016 and 2017, the main areas of field-grown cucurbit production in Morocco (Loukkos, Gharb, Bouznika, Doukkala and Souss) were surveyed for the occurrence and distribution of viruses of zucchini squash. A total of 38 commercial fields were visited and inspected for symptoms of virus diseases and 415 leaf samples were collected from plants showing virus-like symptoms for laboratory analyses. ELISA technique was used to detect the following viruses: Zucchini yellow mosaic virus (ZYMV), Squash mosaic virus (SqMV), Cucumber mosaic virus (CMV), Papaya ringspot virus-watermelon strain (PRSV-W) and Cucurbit aphid-borne yellows virus (CABYV). The obtained results showed that virus diseases were widely distributed in the country with an infection rate of $77.6 \%$, especially in the region of Loukkos where $85 \%$ of the tested plants were infected by at least one virus. To the best of our knowledge, this is the first study on the occurrence and geographical distribution of viruses infecting zucchini squash in Morocco. This study provides valuable information, which could be beneficial and of great interest for the researchers, growers and the plant protection services for planning future strategies to control virus diseases of zucchini squash in Morocco.
\end{abstract}

Keywords: Zucchini squash, virus, Morocco 


\section{Introduction}

The Cucurbitaceae family is the second largest horticultural family in terms of economic importance after Solanaceae. It includes several important crops, such as melon (Cucumis melo), watermelon (Citrullus lanatus), cucumber (Cucumis sativus) and many Cucurbita species with edible fruits (Jeffrey, 1980). Zucchini squash, Cucurbita pepo L., including a wide assortment of varieties and cultivars, is one of the most economically important vegetable crops in Morocco. In open field or under greenhouses, zucchini squash is grown in most areas of the country. Virus diseases are a major constraint in commercial cucurbit production (Lovisolo, 1980; Provvidenti, 1996), causing sporadic epidemics. At least 39 different viruses have been reported to cause cucurbit diseases and many are responsible for economic losses in the quality and quantity of cucurbit crops (Lecoq, 2003; Lecoq et al., 1998; Provvidenti, 1996). In Morocco, zucchini squash is commonly showing typical symptoms of virus infection, including leaf mosaic (variegated patterns of dark and light green to yellow that form a mosaic), leaf distortion and fruit deformation. Indeed, great losses were usually encountered in the country because lumpy and misshapen fruits are unmarketable. Plant viruses are a persistent threat to the production of zucchini squash throughout Morocco, although severe outbreaks tend to occur on a sporadic basis. Proper virus identification and knowledge about which viruses are likely to be the most prevalent allow growers to make better decisions on disease management. In Morocco, very little information is available about frequency and distribution of viruses that occur regularly in cucurbits including zucchini squash. The objective of this research was to assess the distribution and frequency of major viruses affecting zucchini squash in Morocco.

\section{Material and methods}

Surveys of viruses infecting zucchini squash were conducted during the growing seasons 2015, 2016, 2017 and 2018 in the main cucurbit cultivation areas along the Moroccan coast (Loukkos, Gharb, Bouznika, Doukkala and Souss). In the spring of each growing season, samples were collected randomly from plants showing virus-like symptoms throughout the field in each region. Numbers of samples were collected according to the size of the field and the number of planted varieties. In total, 415 samples were collected from 38 fields as reported in Table 1. About two to three leaves per sample were collected from the shoot apex of symptomatic plants and were labelled and placed in separate plastic bags. Samples were transported to the laboratory on ice and kept at $4{ }^{\circ} \mathrm{C}$. All samples were processed within $24 \mathrm{~h}$ of collection. All samples were tested by ELISA using commercially available kits (Sediag, France), according to the manufacturer's instructions, to detect the following viruses: Zucchini yellow mosaic virus (ZYMV), Squash mosaic 
virus (SqMV), Cucumber mosaic virus (CMV), Papaya ringspot viruswatermelon strain (PRSV-W) and Cucurbit aphid-borne yellows virus (CABYV). Reactions of ELISA were measured spectrophotometrically at 405 nm using an ELx800 ELISA reader (BioTek Instruments, USA). Virus positive and negative controls were included in all tests. Two wells were used per sample. The test was considered positive when the mean absorbance value was over twice that of healthy controls.

\section{Results and discussion}

Field visits revealed a high incidence of symptoms caused by commonly prevalent viruses on zucchini squash plants in all the surveyed regions and reached $100 \%$ in some fields, mainly in Loukkos. Symptoms varied from mild mosaic or vein banding, to severe mosaic and malformation, mottling, stunting, leaf rolling and upward cupping, vein clearing, yellowing and reduction of leaf and fruit size. Some plants also showed blistering, colour breaking of fruit, ringspots and fruit deformations. Due to mixed infections, it was difficult to identify the symptoms of a particular virus in the field. Virus diseases typically go unnoticed by growers, unless symptoms are observed on more than 10 to $20 \%$ of plants in a field, or fruit set is significantly reduced (Ali et al., 2012). In symptomatic virus infections, the only positive role of symptoms in the identification of viruses is that it shows a clear difference between virus infected and healthy plants in the field. However, it is difficult to identify a specific virus on zucchini squash based on symptoms alone, because of the possibility of asymptomatic or mixed virus infections, and confusion with abiotic disorders, such as nutrient deficiencies. In addition, different viruses can produce similar symptoms or different strains of a virus cause distinct symptoms in the same host. As well, many factors such as virus strain, host plant cultivar/variety, time of infection, and the environment can influence the symptoms exhibited (Matthews, 1980). While symptoms provide vital information on virus diseases, adequate field experience is required when making a decision on symptomatology alone (Naidu and Hughes, 2001). Usually, it is necessary that visual inspection for symptoms in the field is done in conjunction with other confirmatory tests to ensure accurate diagnosis of virus infection (Bock, 1982).

The relative frequencies of the different viruses infecting zucchini squash are reported in Table 1 and in Figure 1. Of the 415 collected samples, 322 were infected by at least one virus, which represents an infection rate of $77.6 \%$. Single infections accounted for 31.08\% (129/415) of the samples collected from plants. Mixed virus infections were common involving two $(26 \%)$, three $(18.3 \%)$ or four viruses $(2.2 \%)$ in various combinations. No plant was found to be infected by five viruses encountered in the survey. Results showed the highest incidence for ZYMV (42.6\%), followed by SqMV (32.5\%) 
and CABYV (29.9\%) among the collected samples. CMV and PRSV-W were detected in 23.6 and $18.1 \%$ of the samples, respectively. Even collected from plants showing virus-like symptoms, 22.4\% (93/415) of the collected samples were tested negative against the five assayed viruses, suggesting that other viruses might be present. For confirmatory tests, 10 representative positive and negative samples for each virus (ZYMV, SqMV, CMV, PRSV-W, and CABYV) were selected and submitted for additional RT-PCR assays using specific primers (Bau et al., 2003; Juarez et al., 2004; Svobosa and LeisovaSvobodova, 2011; Milojević et al., 2012; Nagendran et al., 2015). Positive and negative controls were included, for each virus, in the assay; as expected, for each tested virus, the RT-PCR obtained results were fully in agreement with those obtained using ELISA (results not shown). Abou-Jawdah et al. (1999) found that ZYMV and CABYV are the most common viruses of field-grown cucurbits in Lebanon, followed by WMV, PRSV-W and to a lesser extent CMV. ZYMV is efficiently aphid-transmitted in a nonpersistent manner and it is also seed borne in zucchini squash (Desbiez and Lecoq, 1997), which could have contributed to its high incidence in field-grown zucchini squash in Morocco. Cucurbit crops infected at an early stage are severely affected by ZYMV. Blua and Perring (1989) showed that early ZYMV infection can cause as much as $94 \%$ reduction of marketable cantaloupe. A similar effect was observed in zucchini squash; the earlier the infection the lower the total number of fruit per plant (Walkey et al., 1992). Only early spring crops may escape high disease incidence. All five viruses were detected in samples collected in all five regions. Loukkos region was the most infected where $85 \%$ of the collected samples were infected by at least one virus, followed by Bouznika (82.7\%), Gharb (74.7\%), Souss (75.7\%) and Oualidiya (72.9\%). This variation in the incidence of these viruses in different locations could be due to the initial sources of inocula, hosts, locations, and transmission vectors early in the season (Ali et al., 2012). It was interesting that the incidence of CMV was very low compared with ZYMV, SqMV and CABYV. The reason for this limited distribution is unknown. CMV has a wide host range, infecting more than 1,200 plant species in 100 families (Edwardson and Christie, 1991), and occurs worldwide, including Morocco. It is possible that the CMV inoculum sources, whether infected seed or aphid vectors, were not abundant to spread more CMV. During the field surveys, the high incidence of mosaic and leaf deformation tended to mask the yellowing symptoms induced by CABYV. This explains why the infection passed unnoticed for several years. Only recently attention has been drawn to CABYV (Aarabe et al., 2018), while the presence of ZYMV was reported previously (Desbiez and Lecoq, 1997). Lecoq et al. (1992) reported that early infections with CABYV may lead to approximately $50 \%$ yield loss in cucumber and $40 \%$ in melon. 
Management of viral diseases of zucchini squash and other cucurbits is of utmost importance in order to safeguard yields of cucurbit crops in Morocco. The accurate and rapid identification of the organisms that cause plant disease is essential for effective disease control. It enables more informed decisions to be made about cultivar choice and how and when chemicals can be used most effectively to control disease epidemics. Various strategies have been employed in the management of cucurbit viral diseases, including removal of weeds and volunteer cucurbit crop plants (Sharma et al., 2016), use of super reflective plastic mulch (Stapleton and Summers, 2002); the use of beneficial insects to control aphids (Kos et al., 2008), and the application of insecticides (Sharma et al., 2016). Planting date based strategies have been in the avoidance and management used (Kone et al., 2017). The most effective and simplest strategy of controlling viral diseases is growing resistant varieties. Use of virus-resistant cultivars has been shown to be a highly effective way to combat virus disease of cucurbits (Sikora et al., 2006). There are few reports on successful use of cross-protection with a mild strain of ZYMV for the control of ZYMV in France (Lecoq et al., 1991), Taiwan (Wang et al., 1991) and the UK (Walkey et al., 1992).

Table 1. The relative frequencies of the major viruses infecting zucchini squash in Morocco as determined by ELISA.

\begin{tabular}{|c|c|c|c|c|c|c|c|c|c|c|c|c|c|c|c|}
\hline \multirow[t]{2}{*}{ Region } & \multirow{2}{*}{$\begin{array}{c}\text { Sampled } \\
\text { fields } \\
\text { (No.) }\end{array}$} & \multirow[t]{2}{*}{$\begin{array}{c}\text { No. } \\
\text { Varieties }\end{array}$} & \multirow{2}{*}{$\begin{array}{c}\text { Tested } \\
\text { plants } \\
\text { No. }\end{array}$} & \multicolumn{2}{|c|}{$\begin{array}{c}\text { Infected } \\
\text { plants }\end{array}$} & \multicolumn{2}{|c|}{ ZYMV } & \multicolumn{2}{|c|}{ CMV } & \multicolumn{2}{|c|}{ SqMV } & \multicolumn{2}{|c|}{ PRSV-W } & \multicolumn{2}{|c|}{ CABYV } \\
\hline & & & & No. & $\%$ & No. & $\%$ & No. & $\%$ & No. & $\%$ & No. & $\%$ & No. & $\%$ \\
\hline Bouznika & 10 & 3 & 87 & 72 & 82.7 & 32 & 36.8 & 25 & 28.7 & 31 & 35.6 & 18 & 20.7 & 30 & 34.5 \\
\hline Gharb & 9 & 3 & 95 & 71 & 74.7 & 37 & 38.9 & 23 & 24.2 & 27 & 28.4 & 15 & 15.8 & 29 & 30.5 \\
\hline Loukkos & 7 & 3 & 60 & 51 & 85 & 30 & 50 & 15 & 25 & 15 & 25 & 14 & 23.3 & 20 & 33.3 \\
\hline Oualidiya & 8 & 3 & 107 & 78 & 72.9 & 48 & 44.9 & 27 & 25.2 & 38 & 35.5 & 17 & 15.9 & 28 & 26.2 \\
\hline Souss & 4 & 3 & 66 & 50 & 75.7 & 30 & 45.4 & 8 & 12.1 & 24 & 36.3 & 11 & 16.7 & 17 & 25.7 \\
\hline Total & 38 & 3 & 415 & 322 & 77.6 & 177 & 42.6 & 98 & 23.6 & 135 & 32.5 & 75 & 18.1 & 124 & 29.9 \\
\hline
\end{tabular}




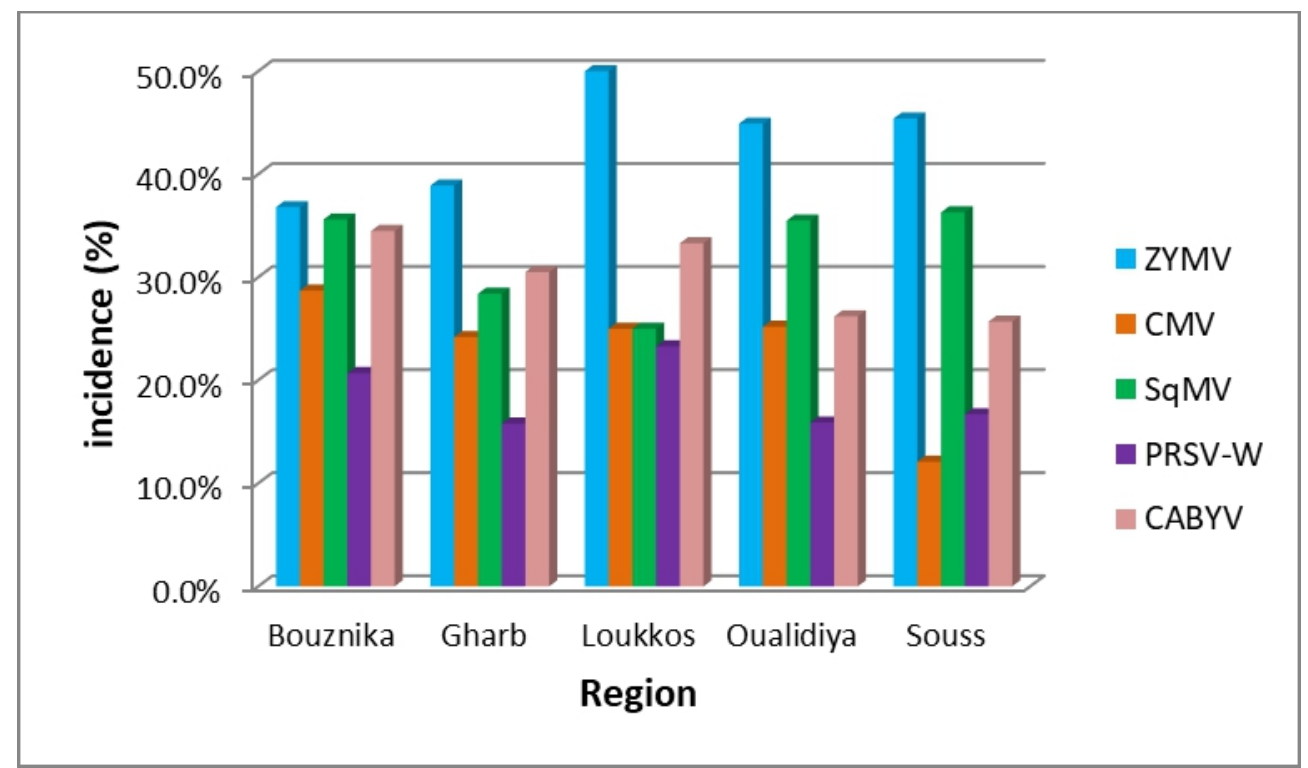

Figure 1. The incidence of the major viruses infecting zucchini squash in Morocco by region as determined by ELISA.

\section{Conclusion}

This work illustrates the distribution and frequency of major emerging viruses found in zucchini squash fields in five main cucurbit-growing areas of Morocco. Results showed that virus diseases were widely distributed in the country with an infection rate of $77.6 \%$. This information should help establishing a basis for the control of viral epidemics in Moroccan field-grown zucchini squash. It is important to identify the most common and damaging viruses in a locality to allow development of a comprehensive management strategy that growers can utilize to reduce losses from these economically important diseases. ZYMV, CABYV, CMV and PRSV-W are transmitted by aphids and are difficult to control. Early infection can significantly reduce yield of cucurbits. Damage can be minimized through the use of integrated pest management strategies. Aphid populations can be reduced through the use of insecticides combined with cultural practices, such as border crops and reflective mulches. Use of virus-resistant cultivars has been shown to be a highly effective way to combat virus disease of cucurbits. Information about the virus infection of weeds with viruses infecting zucchini squash will be helpful in future control strategies for growers in Morocco by allowing them to eradicate sources of infection within or around the field that could then reduce the level of virus inoculum. Further studies are planned to identify vectors of the known viruses and characterize viruses perpetuating in weed species within or adjacent to zucchini squash fields in Morocco. 


\section{References:}

1. Aarabe, A., Chebli, B., \& Afechtal, M. (2018). First report of Cucurbit aphid-borne yellows virus from Morocco. Australas. Plant Dis. Notes 13: 29. https://doi.org/10.1007/s13314-018-0312-7

2. Abou-Jawdah, Y., Sobh, H., El-Zammar, S., Fayyad, A. \& Lecoq, H. (2001). Incidence and management of virus diseases of cucurbits in Lebanon. Crop Prot. 19: 217-224. https://doi.org/10.1016/S02612194(99)00100-3

3. Ali, A., Abdalla, O., Bruton, B., Fish, W., Sikora, E., Zhang, S. \& Taylor, M. (2012). Occurrence of viruses infecting watermelon, other cucurbits, and weeds in the parts of southern United States. Online. Plant Health Prog. https://doi.org/10.1094/PHP-2012-0824-01-RS

4. Bau, H.-J., Cheng, Y.-H., Yu, T.-A., Yang, J.-S. \& Yeh, S.-D. (2003). Broad-spectrum resistance to different geographic strains of Papaya ringspot virus in coat protein gene transgenic papaya. Phytopathol. 93: 112-120. https://doi.org/10.1094/PHYTO.2003.93.1.112

5. Blua, M.J. \& Perring, T.M. (1989). Effect of Zucchini yellow mosaic virus on development and yield of cantaloupe (Cucumis melo). Plant Dis. 73: 317-320. https://doi.org/10.1094/PD-73-0317

6. Bock, K.R. (1982). The identification and partial characterization of plant viruses in the tropics. Trop. Pest Manag. 28: 399-411. https://doi.org/10.1080/09670878209370747

7. Desbiez, C. \& Lecoq, H. (1997). Zucchini yellow mosaic virus Review. Plant Pathol. 46: 809-829. https://onlinelibrary.wiley.com/doi/epdf/10.1046/j.13653059.1997.d01-87.x

8. Edwardson, J.R. \& Christie, R.G. (1991). Cucumoviruses. In: Edwardson, J.R., Christie, R.G. (Eds.), CRC Handbook of viruses infecting legumes. CRC Press, Boca Raton, Fla, pp. 293-319. https://www.cabdirect.org/cabdirect/abstract/19922320732

9. Jeffrey, C. (1980). A review of the Cucurbitaceae. Bot. J. Linn Soc. 81: 233-247. https://doi.org/10.1111/j.1095-8339.1980.tb01676.x

10. Juarez, M., Truniger, V. \& Aranda, M.A. (2004). First report of Cucurbit aphid-borne yellows virus in Spain. Plant Dis. 88: 907. https://doi.org/10.1094/PDIS.2004.88.8.907A

11. Kone, N., Asare-Bediako, E., Silue, S., Kone, D., Koita, O., Menzel, W. \& Winter, S. (2017). Influence of planting date on incidence and severity of viral diseases of cucurbits under field conditions. Ann. Agric. Sci. 62: 99-104. https://doi.org/10.1016/j.aoas.2017.05.005

12. Kos, K., Tomanovic, Z., Petrovic-Obradovic, O., Laznik, Z., Vidrih, M. \& Trdan, S. (2008). Aphids (Aphididae) and their parasitoids in 
selected vegetable ecosystems in Slovenia. Acta Agric. Slov. 91: 1522. https://doi.org/10.2478/v10014-008-0002-9

13. Lecoq, H. (2003). Cucurbits. In: Loebenstein, G., Thottapilly, G. (Eds.), Virus and virus-like diseases of major crops in developing countries. Kluwer Academic Publishers, Dordrecht, The Netherlands, pp. 665-687. https://www.springer.com/gp/book/9781402012303

14. Lecoq, H., Wilser, G. \& Pitrat, M. (1998). Cucurbit viruses: the classics and the emerging. In: McCreight, J.D. (Eds.), Cucurbitaceae '98: Evaluation and enhancement of cucurbits germplasm. American Society of Horticultural Sciences, Alexandria VA, pp. 126-142. https://naldc.nal.usda.gov/download/29241/PDF

15. Lecoq, H., Bourdin, D., Wipf-Scheibel, C., Bon, M., Lot, H., Lemaire, O. \& Herrbach, E. (1992). A new yellowing disease of cucurbits caused by a luteovirus, cucurbit aphid-borne yellows virus. Plant Pathol. 41: 749-761. http://dx.doi.org/10.1111/j.13653059.1992.tb02559.x

16. Lecoq, H., Lemaire, J.M. \& Wipf-Scheibel, C. (1991). Control of Zucchini yellow mosaic virus in squash by cross-protection. Plant Dis. 75: 208-211. http://dx.doi.org/10.1094/PD-75-0208

17. Lovisolo, O. (1980). Virus and viroid disease of cucurbits. Acta Hortic. 88: 33-82. https://doi.org/10.17660/ActaHortic.1981.88.3

18. Matthews, R.E.F. (1980). Host plant responses to virus infection. In: Fraenkel-Conrat, H., Wagner, R.R. (Eds.), Comprehensive virology, vol. 16, virus-host interaction, viral invasion, persistence, and diagnosis. Plenum Press, New York, USA, pp. 297-359. https://doi.org/10.1007/978-1-4613-3129-2_7

19. Milojević, K., Stanković, I., Vučurović, A., Ristić, D., Nikolić, D., Bulajić, A. \& Krstić, B. (2012). First report of Cucumber mosaic virus infecting watermelon in Serbia. Plant Dis. 96: 1706. https://doi.org/10.1094/PDIS-07-12-0631-PDN

20. Nagendran, K., Balaji, C.G., Mohankumar, S., Manoranjitham, S.K., Naidu, R.A. \& Karthikeyan, G. (2015). First report of Zucchini yellow mosaic virus in snake gourd (Trichosanthes cucumerina) in India. Plant Dis. 99: 558. https://doi.org/10.1094/PDIS-10-14-1075-PDN

21. Naidu, R.A. \& Hughes, J.d'A. (2001). Methods for the detection of plant virus diseases. In: Hughes, J.d'A., Odu, B.O. (Eds.), Plant virology in sub-Saharan Africa. Proceedings of a Conference Organized by IITA, June 4-8 2001, International Institute of Tropical Agriculture, Nigeria, pp. 233-260. https://books.google.co.ma/books?id=NbLlvMhVxxsC\&printsec=fro ntcover $\& h l=f r$ 
22. Provvidenti, R. (1996). Diseases caused by virus. In: Zitter, T.A. (Eds.), Compendium of Cucurbit Diseases. American Phytopathological Society, St. Paul, MN, pp. 37-45.

23. Sharma, A., Katoch, V. \& Rana C. (2016). Important diseases of cucurbitaceous crops and their management. In: Pessarakli, M. (Eds.), Handbook of cucurbits growth, cultural practices, and physiology, CRC press 2016, First edition, pp. 301-324.

24. Sikora, E.J., Murphy, J.F. \& Burkett, J. (2006). Performance of virus resistant transgenic yellow summer squash in Alabama. Journal of Vegetable Science 12: 75-83. https://doi.org/10.1300/J484v12n02_07

25. Stapleton, J.J. \& Summers, C.G. (2002). Reflective mulches for management of aphids and aphid-borne virus diseases in late-season cantaloupe (Cucumis melo L. var. cantalupensis). Crop Prot. 21: 891898. https://doi.org/10.1016/S0261-2194(02)00055-8

26. Svobosa, J. \& Leisova-Svobodova, L. (2011). First report of Squash mosaic virus in ornamental pumpkin in the Czech Republic. Plant Dis. 95: 1321. http://dx.doi.org/10.1094/PDIS-05-11-0444

27. Walkey, D.G.A., Lecoq, H., Collier, R. \& Dobson, S. (1992). Studies on the control of Zucchini yellow mosaic virus in courgettes by mild strain protection. Plant Pathol. 41: 762-771. https://doi.org/10.1111/j.1365-3059.1992.tb02560.x

28. Wang, H.L., Gonsalves, D., Provvidenti, R. \& Lecoq H. (1991). Effectiveness of cross-protection by a mild strain of Zucchini yellow mosaic virus in cucumber, melon and squash. Plant Dis. 75, 203207.https://www.apsnet.org/publications/PlantDisease/BackIssues/Do cuments/1991Articles/PlantDisease75n02_203.PDF 